\section{THE SEDATIVE EFFECTS OF VAPOROUS ETHER RECOGNISED FORTY YEARS SINCE. \\ To the Editor of The LANCET.}

SrR,-IIow long the etherial suspension of feeling for the moment has been practised to assuage pain or anguish may be worth investigation. Perhaps the following fact may assist the inquiry:-The hapless mame of an eccentric practitioner will yet be remembered by some who, like me, have reached an advanced age. That gentleman, Dr. Graham, was accus tomed to inhale the vapour from an ounce or two of ether several times a day. I once witnessed his modus operandi, in a drug shop at Bristol, about the year 1802 or 3. He was sitting at the counter, with his thumb over the mouth of a two-ounce phial, sniffing its vaporous contents every now and then, with manifest placidity and self-enjoyment. Being known to me, I took the liberty of asking him what he felt on the occasion. "Soothing, soothing," replied he, "to an immeasurable degree." $\mathrm{\Lambda}$ r. Shedden, the druggist, told me that it was the Doctor's custom, whilst in Bristol, to drop in $t_{\text {wice }}$ or thrice a day, and sniff his dose, always expressing himself as being much gratified by the practice. The Doctor's name became associated with the "celestial bed" and with "earth sweating" panaceas of that time, like the water-cure or the atomic M.M. of modern days. You may, perhaps, recomise as the name of a former contributor to your valuable publication the signature of yours, very respectfully,

Bexliy II cath, Kent, Jan. 1817.

Trros. LeE.

\section{SECRETION OF MILK IN A NEW-BORN INFANT.} To the Editor of THE LANCET.

Sir,-I have now (Jan. 22nd, 1847) under treatment a female infant, aged three weeks, each of whose mammary glands is as large as a walnut. There is a continual secretion and oozing of milk. The mother (delivered in Dunmow Union Fouse, Essex) informs me she observed this "swelling" from the child's birth.

Should this fact be as singular as I suppose, I am perhaps justified in forwarding it to THE LAXCET.

Hatfield, Broad Oak, Essex, John Coventre, Surgeon. Jan. 1847 .

\section{Semedical \$2ens.}

Antr-Quackery.-The Scotch Reformers Gazette is another Glasgow newspaper from the pages of which all quack advertisements are banished. The conductors of such journals universally distinguish themselves from the editors and proprietors of such metropolitan papers as the Pictorial Times, in which the grossest quackery is entertained, and those numerous provincial journals, in which the publishers are agents and dealers in quack medicines and the obscene quack books.

Academie de Medecine.-M. Begin has been elected Pre. sident of the Académie de Médecine, Paris, for the year 1847; M. Bouillaud, Vice-President, and MI. Métier, Secretary.

CAMrRidge. - A medical lecturer has been appointed at Gonville and Caius College, Cambridge, to direct and superintend the studies of the medical students in the College.

Universtry College, London.-As a proof of the estimation in which this academic institution is held in Calcutta, it may be mentioned, that on the intelligence being received in that city of the death of $D$ warkanauth Tagore, a large and influential meeting took place, to adopt measures to commemmorate the admiration of the community for this excellent man. It was thought that no better plan could be adopted than the endowment of a fund intended for the support of native students at this University whilst pursuing their studies, whether professional or general, and to be called the Dwarkanauth Fund. It will be recollected that two native gentlemen have been already educated at this school, with a success that enabled them to carry off the diploma of the Royal College of Surgeons of England. One of them has just returned to Calcutta; the other remains in England, pursuing his studies on comparative anatomy, with a view, it is said, to compete for the appointment of student in that department at the Royal College of Surgeons.

The North London Ophthalmy Instutution.-The annual meeting of the governors of this institution took place on Saturday last, at the Freemasons' Tavern, Sir George Staunton, Bart., M.P., in the chair. The report, which was highly satis- factory, stated, that upwards of 800 patients had been relieved during the past year; of this number, 117 were milliners and others suffering from the effects of overwork of the eyes: and that eighty-nine operations had been performed. This charity is about to be removed to more commodious premises, and will in future be known as the North London Infirmary for Diseases of the Eye.

Stanford and Ruthand Infirmary.-The funds of this Institution have just been augmented by a most munificent bequest from the late Mr. Stephen Rowles, of Stilton, who has left the sum of $£ 350$ per annum for the general purposes of the Institution; and for the express purpose of providing a house-surgeon, a further sum of $£ 100$ per annum. Altogether, this Hospital has been enriched by the princely domation of $£ 10,000$ from this benevolent individual; and it is a curious coincidence that this gentleman was the tenant of Sir Thomas Apreece, who, dying a short time since, left the euormous sum of $£ 6000$ per annum to St. George's Hospital.

A Quack HANDbrLl-M. Francis begs to inform the inhabitants of New Peckham and its neighbourhood, that he has re-opened the shop in Park-row, opposite Trafalgar-square, lately conducted by $\mathbf{S} . \mathbf{H}$. Fysh, chemist and druggist; and trusts, by careful attention, and supplying the most genuine medicines, to receive their support.-Physicians' prescriptions and family receipts will be carefully prepared.-Medical and surgical advice given to the poor (gratis) at all hours.-Bleeding, cupping, dental surgery, \&c., performed at the most reasonable terms.-Advice in ophthalmic diseases on Mondays and Thursdays.-Midwifery attended.

Park-road, opposite Trafalgar-square, New Peckham, Jan. 1847 .

Montality of the Metropolis.- The deaths witlin the week ending January 23 amounted to 1225 , or $15 \%$ above the weekly average for the five past winters. Of these, 531 were from diseases of the lungs, 54 from heart diseases, 50 from hooping-cough, 28 from typhus, 45 from apoplexy and paralysis, and 65 from natural decay. Electricity positive for the six latter days of the week; weather overcast; mean of thermometer, $32^{\circ} 6^{\prime}$. Since the commencement of this year, the district of Lewisham and sub-district of Hampstead have become included in "London," which thus comprises an area of 115 square miles, with a population, in 1811, of $1,948,211$. The deaths within the bills of mortality henceforth will, of course, be materially more numerous in the aggregate; but they may be expected to be less relatively to the population, the additions to the metropolis (on the line of the Brighton and Birmingham Railways) comprising some of the most lealthy districts in its vicinity. Total births, week ending January 23, 1334.

\section{COR RESPONDENTS.}

$J$. $H . B$. The question proposed involves a nice case of couscience. We incline to the opinion, that the medical man fulfilled his duty in urging upon the master and mistress the necessity of search for the body of the child.

$A$ Governor of the Birkenkead Hospital.-There can be no doubt that some period of service ought to be fixed, after which surgeons retiring might properly be elected consulting surgeons, and that the period ought to be a lengthened one, to avoid the anomaly of having a consulting surgeon of much less standing than the actual surgeons to the charity.

Non Viridis.-The Dawson quackery shall not escape us.

A Constant Reader had better address Professor Graham, or the publisher of the "Elements of Chemistry." We are unable to answer his question.

$M r$. Adams. - In our last we inserted some excellent cases of dislocation of tho astragalus. They were kindly furnished by Mr. Adams, of the London Hospital; but the name was omitted in the heading. This explains the use of the personal pronoun throughout.

Iota could not claim ary fee more than an ordinary witness.

Errata.-In page 112, line 23 from the bottom, for sensorium, read tentorium; in page 114 , line 37 from the top, for heal, read treat; and in page 114 , line 38 , for purgative, read purgation.

Communications have been received from-Dr. Sheppard, (Plymouth ;) Mr. Bouverie; Dr. G. Webster; Dr. Tyler Smith; Mr. Eden; M.D., (Bournemouth ;) Dr. Jacob; Mr. C. M. Ashwin; Mr. Vores, (Yarmouth ;) Mr. F. S. Garlick ; W. T., (Putney;) Dr. Milroy; Dr. Taylor; Dr. Day; Mr. Lake; J. H. B.; Viator; A Governor of the Birkenhead Infirmary; Dr. Jeffrey's, (Liverpool;) Mr. J. A. Dorr ; Mr. Handsby, (Abergavenny ;) Dr. J. G. Swayme, (Clifton;) Mr. Rendeil, (Tiverton;) A Constant Rcader; Mr. C. Ray; Sir Philip Crampton; Dr. Addison; Mr. Bell, (Halstead;) Mr. R. L. Freer; Mr. Adams; Justicia; Dr. Power, (Great Queen-street;) Mr. J. G. Lansdown; Dr. Dick; Dr. C. E. H. Orpen; Mr. W. Thompson, (Putney ;) Mr. J. F. Leach ; Dr. Plomley ; Mr. Johnson; One Deformed Mr. Sleman, (Tavistock ;) Mr. Reeves ; Chemicus ; Gratus, \&c. 